\title{
Vacuum-assisted closure therapy guided by C-reactive protein level in patients with deep sternal wound infection
}

Ronny Gustafsson, MD

Per Johnsson, MD, PhD ${ }^{\mathrm{a}}$

Lars Algotsson, MD, $\mathrm{PhD}^{\mathrm{b}}$

Sten Blomquist, $\mathrm{MD}, \mathrm{PhD}^{\mathrm{b}}$

Richard Ingemansson, $\mathrm{MD}, \mathrm{PhD}^{\mathrm{a}}$
From the Departments of Cardiothoracic Surgery $^{\mathrm{a}}$ and Anesthesiology, ${ }^{\mathrm{b}}$ Heart and Lung Division, University Hospital, Lund, Sweden.

Received for publication July 6, 2001; revisions requested Aug 1, 2001; revisions received Aug 17, 2001; accepted for publication Sept 25, 2001

Address for reprints: Ronny Gustafsson, MD, Heart and Lung Division, University Hospital, SE-221 85 Lund, Sweden (Email: ronny.gustafsson@thorax.lu.se).

J Thorac Cardiovasc Surg 2002;123: 895-900

Copyright $(\odot) 2002$ by The American Association for Thoracic Surgery

0022-5223/2002 \$35.00+0 $\quad \mathbf{1 2 / 1 / 1 2 1 3 0 6}$

doi:10.1067/mtc.2002.121306
Background: Deep sternal wound infection is a serious and potentially lethal complication of cardiac surgery when performed through a median sternotomy. We describe the outcome of a new treatment strategy with C-reactive protein levelguided vacuum-assisted closure used at our department.

Methods: Data from 16 consecutive adult patients who had deep sternal wound infections after cardiac surgery were reviewed. Patients with superficial infection or sterile dehiscence were not included. All patients with postoperative deep sternal wound infections were treated with first-line vacuum-assisted closure therapy, followed by direct surgical closure. A purpose-built vacuum-assisted closure system consisting of polyurethane foam pieces and a special pump unit was used. The foam was placed in the wound after debridement of foreign material and necrotic tissue. The wound was covered with adhesive drape and connected to the pump unit, which was programmed to create a continuous negative pressure of $125 \mathrm{~mm} \mathrm{Hg}$ in the wound cavity. Intravenous antibiotics were given according to tissue-culture results. The patients were immediately extubated after the operation. When ingrowth of granulation tissue was observed in all parts of the wound and the plasma C-reactive protein level showed a steady decline to 30 to $70 \mathrm{mg} / \mathrm{L}$ or less without confounding factors, such as tissue injuries or concomitant infections, the sternotomy was rewired, and the wound was closed.

Results: All patients were alive and free from deep sternal wound infection 3 months after the operation. The median vacuum-assisted closure treatment time until surgical closure was 9 days (range, 3-34 days), and the median C-reactive protein level at closure was $45 \mathrm{mg} / \mathrm{L}$ (range, $20-173 \mathrm{mg} / \mathrm{L}$ ). The median hospital stay was 22 days (range, 12-120 days).

Conclusions: Early vacuum-assisted closure treatment, followed by surgical closure guided by the plasma C-reactive protein level, is a reliable and easily applied new strategy in patients with postoperative deep sternal wound infection.

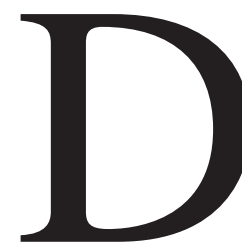

eep sternal wound infection is a serious complication of cardiac surgery with both human and economic consequences. ${ }^{1,2}$ The reported incidence varies from $1 \%$ to $5 \%$ of all sternotomy procedures. ${ }^{3,4}$ Mortality has been reported to range between $0 \%$ and 35\% in different studies..$^{5-7}$ The established treatment at most centers involves surgical debridement, drainage, irrigation, and delayed closure with reconstruction with omentum or a pectoral muscle flap. 7,8 Despite numerous advances in different reconstructive surgical techniques, the infected and frequently dehisced poststernotomy wound continues to be a treatment challenge, and optimal management is still a matter of controversy. The overall aim 
is to find a safe, standardized, and less invasive method to heal these wounds completely by first intention.

In this article we present a new method for postoperative deep sternal wound infection: a combination of vacuumassisted closure with secondary surgical closure of the sternotomy at a time point guided by daily measurements of the systemic plasma concentration of C-reactive protein. The vacuum-assisted closure treatment will increase the elimination rate of bacteria present in the wound, ${ }^{9}$ and this might decrease the amount of inflammatory cytokines released, which, as a result, will affect the initiation of the acutephase reaction with a concomitant decline in systemic plasma C-reactive protein levels. With this new strategy, several aspects of infected wound treatment are combined: objective monitoring, removal of all foreign material, adequate drainage, accelerated granulation, complete coverage, and obliteration of the wound cavity.

\section{Methods}

The most common signs leading to diagnosis were an unstable sternum with secretion, fever, leukocytosis, and high plasma Creactive protein levels. Debridement of clearly necrotic and infected bone tissue was performed at the time of the vacuumassisted closure application. This was carried out in a conservative and bone-saving manner. At the same time, 5 mediastinal tissue cultures were obtained from the wound (Table 1). Antibiotic treatment was started with intravenous vancomycin in all patients. The doses were adjusted according to the renal status of the patients. This treatment continued until the tissue cultures arrived. The regimen was changed according to sensitivity (Table 1). No vancomycin-resistant bacteria were found. The intravenous therapy continued for 7 days after sternal closure. The oral regimen continued for 4 weeks as a combined therapy, according to the sensitivity of the strains.

A sterile polyurethane foam dressing with an open-pore structure of 400 to $600 \mu \mathrm{m}$ (KCI, Copenhagen, Denmark) was trimmed to fit in the wound. The first layer was placed substernally. A second and third layer of polyurethane foam dressing were placed between the sternal edges and the subcutaneous layer, respectively. The open wound was sealed with transparent adhesive drape, which overlapped the wound by 8 to $10 \mathrm{~cm}$. A noncollapsible evacuation tube connected the controlled closed wound to a purpose-built vacuum source. We used a VAC pump unit (KCI), which delivers a continuous or intermittent negative pressure of 25 to $200 \mathrm{~mm} \mathrm{Hg}$. A continuous negative pressure of $125 \mathrm{~mm} \mathrm{Hg}$ was used in all cases. A canister in the pump unit collects the exudate from the wound.

The polyurethane foam dressing was changed twice a week under aseptic conditions. This was done after achievement of full anesthesia. At the time of dressing change, avascular and necrotic bone tissue was demarked with the vacuum-assisted closure therapy by lack of granulation tissue and can easily be removed. Most of the patients were extubated immediately after vacuum-assisted closure application and could leave the intensive care unit after 2 to 3 hours. When visual inspection showed the wound to be well vascularized and covered with granulation tissue and the $\mathrm{C}$-reactive protein level had declined to 30 to $70 \mathrm{mg} / \mathrm{L}$ without confound- ing factors, such as the presence of tissue injuries or infection elsewhere, the wound was considered to be free from infection. The sternotomy was rewired without further debridement with interrupted steel wire (Stahldraht; Johnson and Johnsson, Brussels, Belgium), and the skin was closed with interrupted stitches (Dermalon 2-0; Davis and Geck, St Louis, Mo).

\section{Results}

Between February 1999 and December 2000, 16 consecutive patients with postoperative deep sternal wound infection after cardiac surgery were identified and treated with first-line vacuum-assisted closure therapy. During this time interval, a total of 2201 patients were operated on through a median sternotomy in our institution, giving an incidence of deep sternal wound infection of approximately $0.7 \%$. Thirteen $(81 \%)$ patients were men, and $3(19 \%)$ were women. The median age of the male patients was 68 years (range, 49-82 years), and that for the female patients was 67 years (range, 63-73 years).

The median time between the initial cardiac operation and the diagnosis of deep sternal wound infection was 16 days (range, 3-52 days). The median duration of vacuumassisted closure treatment was 9 days (range, 4-34 days), and the median hospital stay was 22 days (range, 12-120 days). Nine of the 16 patients were able to leave the intensive care unit after 2 to 3 hours of observation (Table 1). The median systemic plasma C-reactive protein level showed a progressive decline during treatment and was 45 $\mathrm{mg} / \mathrm{L}$ (range, $20-173 \mathrm{mg} / \mathrm{L}$ ) at surgical closure of the sternotomy (Figure 1, $A$ ).

All patients were alive and free from sternal infection 3 months after secondary closure. In 2 patients further surgical intervention was necessary because of fistulas after rewiring. These 2 patients had otherwise stable and healed sternotomies.

\section{Discussion}

Sealed negative-pressure treatment was first described in the early 1990s as a method to accelerate wound healing in patients with open fractures ${ }^{10}$ and resulted in the development of a vacuum-assisted closure system. ${ }^{11,12}$ Negativepressure treatment of wounds has been used with success in reconstructive and trauma surgery. ${ }^{13,14}$ A particular benefit of applying vacuum into the wound is to promote healing in complicated cases in which established treatment fails. ${ }^{15}$ Tang and coworkers ${ }^{16}$ successfully treated 15 patients with sternotomy wound infections with vacuum-assisted closure for 22 to 69 days without surgical closure. We consider this a safe method, and the risk of reinfection is low. It was time consuming, and the sternum was not rewired, but this strategy would still be an option in patients who are otherwise obsolete surgical candidates.

Because of our former experience with patients in whom deep sternal wound infection has been treated with major 


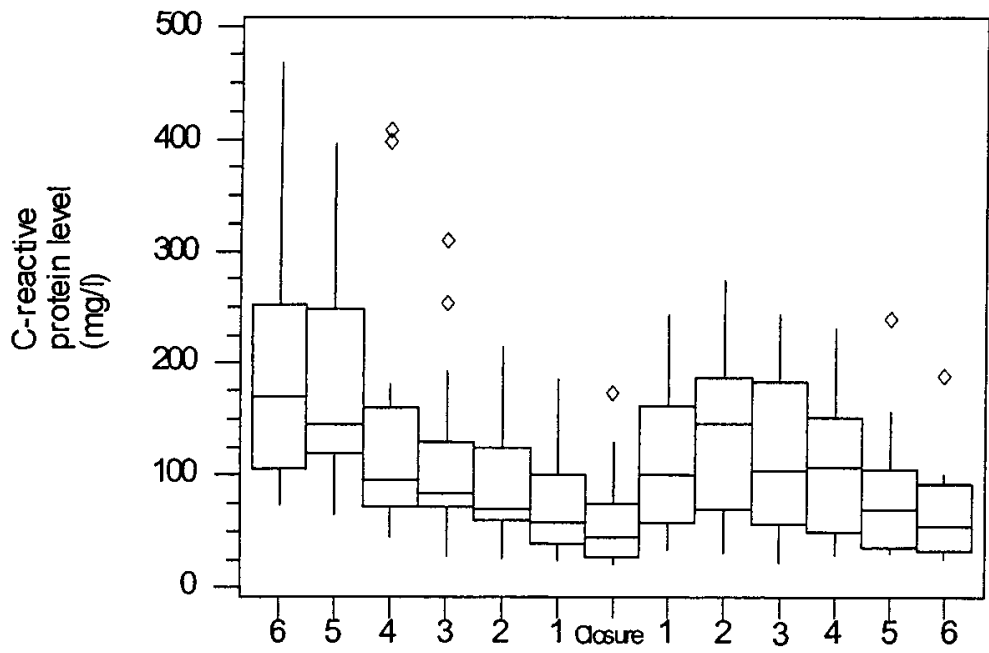

A

Days

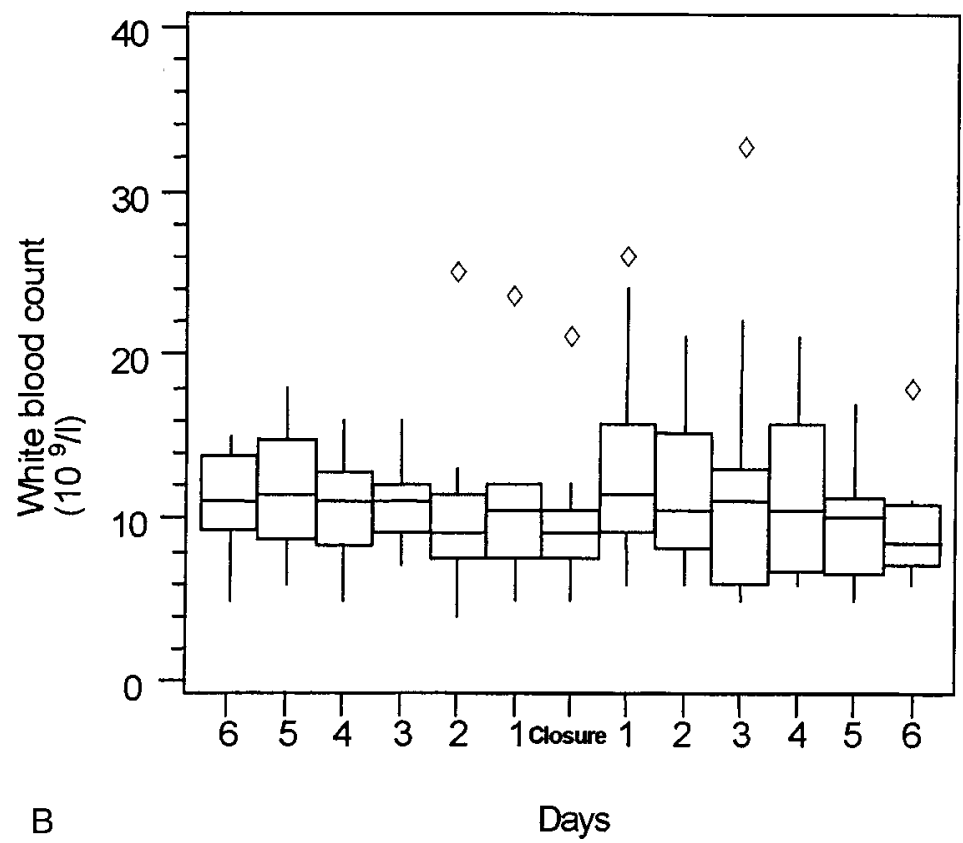

Figure 1. A, Median C-reactive protein levels are presented in a box plot 6 days before and 6 days after sternal closure. The whiskers represent the range of the data, the boxes express the upper and lower quartiles, and the central line shows the median. Diamonds, Outliers. B, Median white blood cell count levels are presented in a box plot 6 days before and 6 days after sternal closure. The whiskers represent the range of the data, the boxes express the upper and lower quartiles, and the central line shows the median. Diamonds, Outliers.

reconstructive surgery, which causes extensive hospitalization and patient morbidity, we developed a new strategy using vacuum-assisted closure for patients with deep sternal wound infection. Serial measurements of systemic C-reactive protein were performed during vacuum-assisted closure and revealed a typical pattern (Figure 1, A). We used this to guide us during the treatment, and closure of the sternum was performed when the plasma levels were progressively declining to 30 to $70 \mathrm{mg} / \mathrm{L}$. At this level, the wound was considered ready for closure. After secondary closure, the C-reactive protein level again rose and reached a peak within 72 hours before declining to preclosure levels. This elevation corresponded to the surgical trauma ${ }^{17}$ and was not a sign of reinfection.

The white blood cell count was helpful for the diagnosis of deep sternal wound infection but did not show a trend 


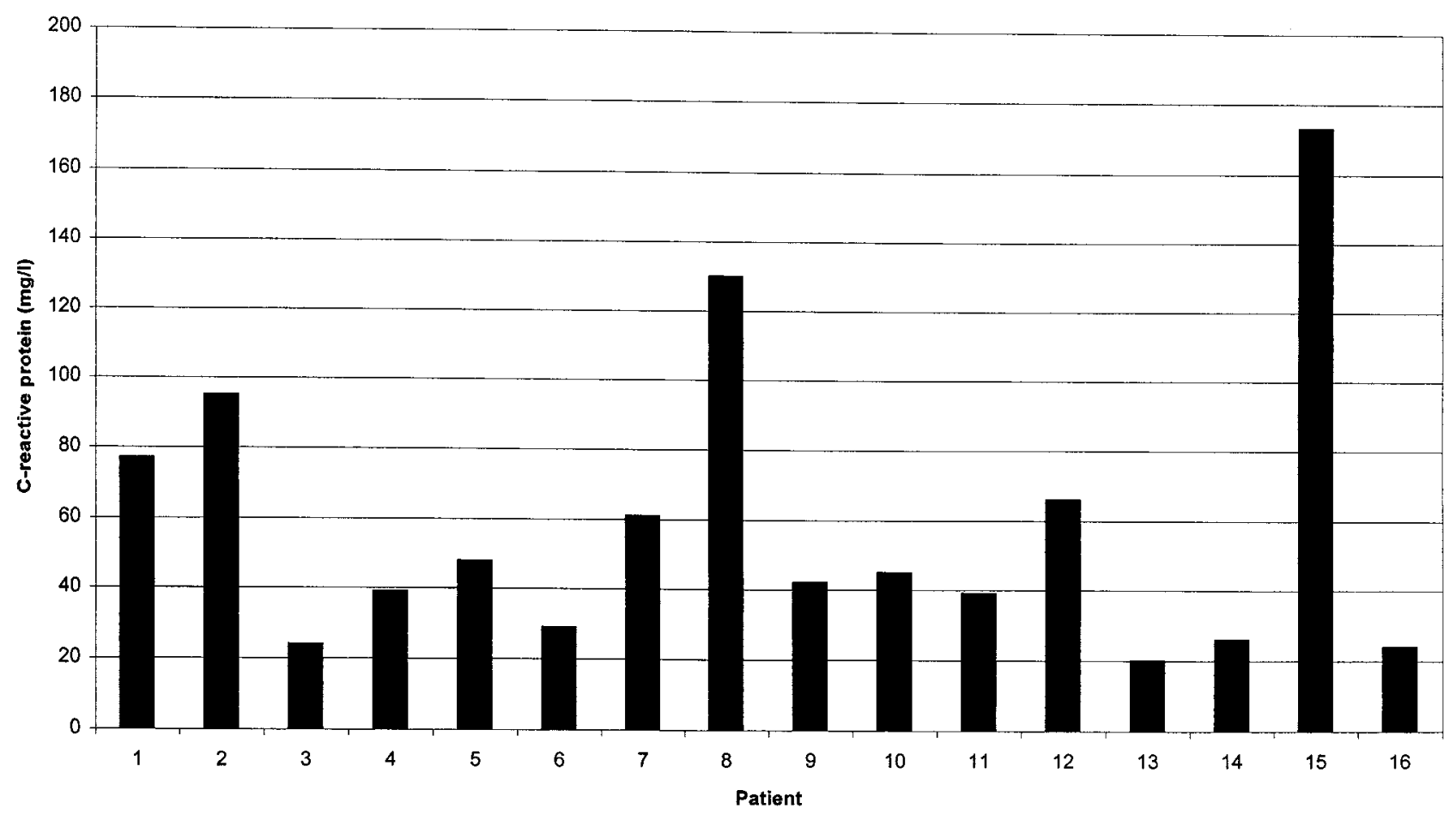

Figure 2. Individual C-reactive protein level at the time of sternal wound closure.

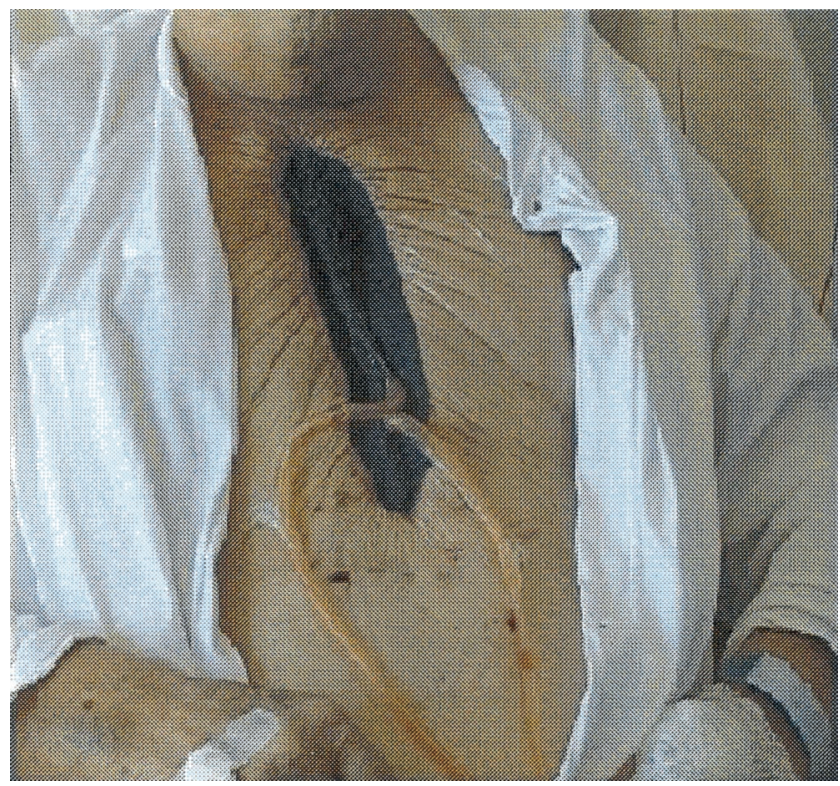

Figure 3. Day 1 after sternal revision and vacuum-assisted closure application. The patient is mobilized in the ward.

useful for guide lining of sternal closure and monitoring of the vacuum-assisted closure therapy (Figure 1, B). We therefore suggest the monitoring of plasma $\mathrm{C}$-reactive protein (Figure 1, A) to be an adjunct for wound control ${ }^{18,19}$ and for assessing the appropriate time for sternal closure during high negative-pressure therapy.

In 3 patients (patients 2, 8, and 15) the sternotomy was rewired despite a markedly persistent elevation in their C-reactive protein values (Figure 2). In these patients the sternal wound was not the source of infection. Two patients (patients 2 and 8 ) were treated for 32 and 34 days, respectively. Patient 2 had a stroke, multiorgan failure, and bilateral pneumonia. Patient 8 had peritonitis and was treated for bowel obstruction caused by chronic peritoneal dialysis. In these 2 patients the C-reactive protein level remained high because of concomitant infection, and they stayed in the hospital for other reasons than sternal infection. Patient 15 had massive pectoral muscle necrosis caused by cardiac resuscitation, followed by an emergency valve operation. The sternum was rewired, and the muscle necrosis was partially resected and separately drained. These 3 patients were moribund as the vacuum-assisted closure therapy was initiated. They recovered but required longer hospitalization because of the complexity of their diseases (Table 1). In cases in which the C-reactive protein level remains high as a result of confounding factors, sternal tissue cultures are required to decide when to close the sternotomy.

The duration of vacuum-assisted closure treatment until sternal closure in a typical patient without other concomitant infection was approximately 7 days (Table 1). During this time, the patient was mobilized in the ward, had no 
TABLE 1. Vacuum-assisted closure in 16 consecutive patients with deep sternal wound infection undergoing cardiac surgery

\begin{tabular}{|c|c|c|c|c|c|c|c|c|c|}
\hline $\begin{array}{l}\text { Patient } \\
\text { No. }\end{array}$ & $\begin{array}{c}\text { Age } \\
\text { (y) }\end{array}$ & Sex & Procedure & Mediastinal cultures & Antibiotics, intravenous & $\begin{array}{c}\text { Presentation } \\
\text { postoperative day }\end{array}$ & $\begin{array}{l}\text { VAC } \\
\text { (d) }\end{array}$ & $\begin{array}{l}\text { ICU } \\
\text { (d) }\end{array}$ & $\begin{array}{l}\text { Hospitalization } \\
\text { (d) }\end{array}$ \\
\hline 1 & 67 & $\mathrm{~F}$ & CABG & CoNS & Vanco & 16 & 7 & 6 & 19 \\
\hline 2 & 66 & $\mathrm{M}$ & P-Homograft & CoNS & Cipro & 17 & 32 & 32 & 84 \\
\hline 3 & 80 & $\mathrm{M}$ & $C A B G+A V R$ & CoNS & Vanco + Imi & 52 & 4 & 0 & 17 \\
\hline 4 & 82 & $\mathrm{M}$ & CABG & E cloace & Vanco + Cipro & 8 & 6 & 0 & 13 \\
\hline 5 & 63 & $\mathrm{M}$ & CABG & CoNS & Vanco & 20 & 6 & 0 & 17 \\
\hline 6 & 69 & $\mathrm{M}$ & CABG & CoNS & Vanco + Cipro & 13 & 18 & 21 & 28 \\
\hline 7 & 57 & $\mathrm{M}$ & CABG & CoNS & Vanco & 14 & 9 & 0 & 25 \\
\hline 8 & 55 & $\mathrm{M}$ & CABG & CoNS & Vanco & 17 & 34 & 34 & 120 \\
\hline 9 & 73 & $\mathrm{~F}$ & CABG + Alfieri & CoNS & Vanco & 15 & 5 & 0 & 25 \\
\hline 10 & 49 & $\mathrm{M}$ & Ross & CoNS & Vanco & 14 & 3 & 0 & 12 \\
\hline 11 & 68 & $\mathrm{M}$ & CABG & $S$ aureus & Clinda & 13 & 13 & 0 & 19 \\
\hline 12 & 79 & $\mathrm{M}$ & CABG & CoNS & Vanco + Cipro & 7 & 12 & 0 & 31 \\
\hline 13 & 77 & $\mathrm{M}$ & AVR & CoNS & Vanco & 23 & 8 & 3 & 15 \\
\hline 14 & 71 & $\mathrm{M}$ & CABG & CoNS $+E$ coli & Vanco & 18 & 9 & 8 & 49 \\
\hline 15 & 57 & $\mathrm{M}$ & $C A B G+A V R$ & CoNS $+E$ coli & Vanco + Imi & 3 & 9 & 24 & 87 \\
\hline 16 & 63 & $\mathrm{~F}$ & CABG & CoNS & Vanco & 22 & 10 & 0 & 17 \\
\hline
\end{tabular}

Presentation, postoperative day, Days from initial cardiac operation to diagnosis of sternal infection; VAC (d), days with vacuum-assisted closure therapy before sternal rewiring; ICU (d), length of stay in the intensive care unit; $C A B G$, coronary artery bypass grafting; P-Homograft, pulmonary homograft replacement; AVR, aortic valve replacement; Alfieri, mitral valve plasty ad modum Alfieri; Ross, pulmonary autograft; CoNS, coagulase-negative staphylococcus; E. cloace, Enterobactus cloace; E. coli, Escherichia coli; S. aureus, Staphylococcus aureus; Vanco, vancomycin; Cipro, ciprofloxacin; Imi, imipenem; Clinda, clindamycin.

pain, and had practically no need for nursing requirements regarding the wound (Figure 3).

Furthermore, when the vacuum-assisted closure treatment is activated with a negative pressure of $125 \mathrm{~mm} \mathrm{Hg}$, the foam will become firm and act as a splint in the sternum. This enables early mobilization and supports full lung function with no more pain than after a rewired sternotomy. Surgical closure can be carried out when the patient has returned to an anabolic phase without infection and with a profuse bed of fresh granulation tissue in the wound. In addition, our strategy does not require transposition of omentum or muscle flaps.

Most of the patients had positive cultures with vancomycin- or clindamycin-sensitive coagulase-negative staphylococci (Table 1), which is a growing problem among postoperative cardiac patients. ${ }^{2,20}$ Therefore another advantage of this closed and controlled system is a decreased risk of contamination to the environment.

Hemodynamic instability, bleeding tendency, arrhythmia, and chest pain were considered potential problems. However, none of our patients experienced any of these. Some air leakage was noticed but could easily be handled with additional adhesive drape.

Animal studies by Morykwas and coworkers ${ }^{9}$ showed that vacuum-assisted closure accelerated the elimination of edema and bacteria in the wound. Additionally, an increase in blood flow by 3 to 4 times and an accelerated ingrowth of granulation tissue by 2 to 3 times was noted. All these features will increase the wound vascularity, which is of utmost importance for early secondary closure and optimal wound healing in a patient with deep sternal wound infection.

The results presented in this article describe a new strategy for treatment of deep sternal wound infection, with possible positive effects on morbidity and cost-effectiveness. More studies are needed for proper comparison with the standard treatment of early sternectomy and muscle flap closure.

\section{References}

1. Taylor GJ, Mikell FL, Moses HW, Dove JT, Katholi RE, Malik SA, et al. Determinants of hospital charges for coronary artery bypass surgery: the economic consequences of postoperative complications. Am J Cardiol. 1990;65:309-13.

2. Mossad SB, Serkey JM, Longworth DL, Cosgrove DM, Gordon SM. Coagulase-negative staphylococcal sternal wound infections after open heart operations. Ann Thorac Surg. 1997;63:395-401.

3. Sarr MG, Gott VL, Townsend TR. Mediastinal infection after cardiac surgery. Ann Thorac Surg. 1984;38:415-23.

4. Hazelrigg SR, Wellons HA, Schneider JA, Kolm P. Wound complications after median sternotomy. Relationship to internal mammary grafting. J Thorac Cardiovasc Surg. 1989;98:1096-9.

5. Wouters R, Wellens F, Vanermen H, De Geest R, Degrieck I, De Meerleer F. Sternitis and mediastinitis after coronary artery bypass grafting. Analysis of risk factors. Tex Heart Inst J. 1994;21:183-8.

6. Farinas MC, Gald PF, Bernal JM, Rabasa JM, Revuelta JM, GonzalezMacias J. Suppurative mediastinitis after open-heart surgery: a casecontrol study covering a seven-year period in Santander, Spain. Clin Infect Dis. 1995;20:272-9.

7. Rand RP, Cochran RP, Aziz S, Hofer BO, Allen MD, Verrier ED, et al. Prospective trial of catheter irrigation and muscle flaps for sternal wound infection. Ann Thorac Surg. 1998;65:1046-9. 
8. Jones G, Jurkiewicz MJ, Bostwick J, Wood R, Bried JT, Culbertson J, et al. Management of the infected median sternotomy wound with muscle flaps. The Emory 20-year experience. Ann Surg. 1997;225: 766-76.

9. Morykwas MJ, Argenta LC, Shelton-Brown EI, McGuirt W. Vacuum-assisted closure: a new method for wound control and treatment: animal studies and basic foundation. Ann Plast Surg. 1997; 38:553-62.

10. Fleischmann W, Strecker W, Bombelli M, Kinzl L. Vacuum sealing as treatment of soft tissue damage in open fractures. Unfallchirurg. 1993;96:488-92.

11. Argenta LC, Morykwas MJ. Vacuum-assisted closure: a new method for wound control and treatment: clinical experience. Ann Plast Surg. 1997:38:563-76.

12. Voinchet V, Magalon G. Vacuum assisted closure. Wound healing by negative pressure. Ann Chir Plast Esthet. 1996;41:583-9.

13. Greer SE, Longaker MT, Margiotta M, Mathews AJ, Kasabian A. The use of subatmospheric pressure dressing for the coverage of radial forearm free flap donor-site exposed tendon complications. Ann Plast Surg. 1999;43:551-4.
14. Barker DE, Kaufman HJ, Smith LA, Ciraulo DL, Richart CL, Burns RP. Vacuum pack technique of temporary abdominal closure: a 7-year experience with 112 patients. J Trauma. 2000;48:201-6.

15. Blackburn JH, Boemi L, Hall WW, Jeffords K, Hauck RM, Banducci DR, et al. Negative-pressure dressings as a bolster for skin grafts. Ann Plast Surg. 1998;40:453-7.

16. Tang AT, Ohri SK, Haw MP. Novel application of vacuum assisted closure technique to the treatment of sternotomy wound infection. Eur J Cardiothorac Surg. 2000;17:482-4.

17. Pritchett JW. C-reactive protein levels determine the severity of softtissue injuries. Am J Orthop. 1996;25:759-61.

18. Icard P, Fleury JP, Regnard JF, Libert JM, Magdeleinat P, Gharbi $\mathrm{N}$, et al. Utility of C-reactive protein measurements for empyema diagnosis after pneumonectomy. Ann Thorac Surg. 1994;57:933-6.

19. Du Clos TW. Function of C-reactive protein. Ann Med. 2000;32: 274-8.

20. Tegnell A, Aren C, Ohman L. Coagulase-negative staphylococci and sternal infections after cardiac operation. Ann Thorac Surg. 2000;69: 1104-9. 